\title{
Replication of recently identified associated single-nucleotide polymorphisms from six autoimmune diseases in Genetic Analysis Workshop 16 rheumatoid arthritis data Harshal Deshmukh, Xana Kim-Howard and Swapan K Nath*
}

Address: Genetic Epidemiology Unit, Arthritis and Immunology Research Program, Oklahoma Medical Research Foundation, 825 Northeast 13th Street, Oklahoma City, Oklahoma 73104 USA

E-mail: Harshal Deshmukh - harshal-deshmukh@omrf.org; Xana Kim-Howard - Xana-Kim@omrf.org; Swapan K Nath* - Swapan-Nath@omrf.org

${ }^{*}$ Corresponding author

from Genetic Analysis Workshop 16

St Louis, MO, USA 17-20 September 2009

Published: 15 December 2009

BMC Proceedings 2009, 3(Suppl 7):S31 doi: 10.1186/1753-6561-3-S7-S31

This article is available from: http://www.biomedcentral.com/I753-656I/3/S7/S3I

(C) 2009 Deshmukh et al; licensee BioMed Central Ltd.

This is an open access article distributed under the terms of the Creative Commons Attribution License (http://creativecommons.org/licenses/by/2.0), which permits unrestricted use, distribution, and reproduction in any medium, provided the original work is properly cited.

\begin{abstract}
Many autoimmune diseases share similar underlying pathology and have a tendency to cluster within families, giving rise to the concept of shared susceptibility genes among them. In the Genetic Analysis Workshop 16 rheumatoid arthritis (RA) data we sought to replicate the genetic association between single-nucleotide polymorphisms (SNPs) identified in recent genome-wide association studies (GWAS) on RA and five other autoimmune diseases. We identified 164 significantly associated non-HLA SNPs $\left(p<10^{-5}\right)$ from 16 GWAS and 13 candidate gene studies on six different autoimmune diseases, including RA, systemic lupus erythematosus, type I diabetes, Crohn disease, multiple sclerosis, and celiac disease. Using both direct and imputation-based association test, we replicated 16 shared susceptibility regions involving RA and at least one of the other autoimmune diseases. We also identified hidden population structure within cases and controls in Genetic Analysis Workshop 16 RA data and assessed the effect of population structure on the shared autoimmunity regions. Because multiple autoimmune diseases share common genetic origin, these could be areas of immense interest for further genetic and clinical association studies.
\end{abstract}

\section{Background}

Autoimmune diseases affect $5 \%$ of the human population [1]. Although there is considerable heterogeneity among these disorders, their manifestations are believed to arise from immune-mediated attack against selfantigens. Despite their clinical heterogeneity, recent studies examining gene expression profiles in peripheral blood mononuclear cells (PBMC) of individuals with autoimmune disorders reveal common features that are either shared within a disease group or among disease groups as exemplified in rheumatoid arthritis (RA) [2] or in systemic lupus erythematosus (SLE) [3]. The major symptoms of RA arise through immune-mediated destruction of peripheral joints; however, these features 
are typically accompanied by systemic complications such as rheumatoid nodules and vasculitis. Immunemediated destruction is the central feature of autoimmune diseases like SLE, type 1 diabetes (T1D), multiple sclerosis (MS), and celiac disease (CLD). Given the similarities in the basic pathology of these autoimmune disorders, it is not surprising to see autoimmune diseases clustering within families, which leads to the hypothesis of common autoimmunity genes being shared between diseases. An example of such shared gene is Runx1, which is shown to be associated with SLE, psoriasis, and RA [4]. Increasing numbers of GWAS for autoimmune disorders have enhanced the possibility of identifying such shared autoimmune regions.

The goals of the present study are 1) to identify population structure in Genetic Analysis Workshop (GAW) 16 RA cases and controls, 2) to replicate the genetic association in RA identified from recent GWAS on six common autoimmune diseases [RA, Crohn disease (CD), CLD, SLE, MS, and T1D], and 3) to study the effect of admixture on associated regions.

\section{Methods}

After searching the PubMed database we identified recently published 16 GWAS and other 13 candidate gene association studies [5-28] on RA, CD, SLE, MS, CLD, and T1D. SNPs which showed significant association at a genome-wide "suggestive" threshold $\left(p<10^{-5}\right)$ were chosen for replication in GAW16 RA data. The preselected threshold $\left(p<10^{-5}\right)$ was chosen as "suggestive" to control properly the family-wide type 1 error as recommended by Duggal et al. [29] to adjust $p$-value to control the family-wide type 1 error in genome-wide association studies. The rationale for choosing this threshold was to maximize true associations from the GWAS. We performed an association analysis using predefined quality control criteria (MAF $\geq 1 \%$, SNP missingness rate of $\leq 10 \%$, and Hardy-Weinberg equilibrium $\geq 0.001$ in controls) and identified significant SNPs for RA either by direct association using PLINK [30] or by imputation using fastPHASE [31].

To identify the hidden population structure in cases and controls, we estimated and compared the likelihood of this data under different numbers of ancestral populations $(k)$. We used STRUCTURE [32] for estimating the best $k$ separately for cases and controls. We identified 343 ancestry informative markers (AIMs) from two previously published reports $[33,34]$ that were available in GAW16 RA data. These AIMs were used in both estimating population structure and admixture proportion in each individual, as well as correcting for the effect of population substructure in genetic association. We employed two different methods for controlling the effect of population substructure, i.e., structured association test (SAT) [35] with 10,000 permutations and covariate-adjusted logistic regression. We also included sex as a covariate in the logistic regression model; however, it did not significantly affect the association results and was excluded from the final model. To corroborate the evidence of population structure we performed principal-component analysis using EIGENSOFT. We evaluated the statistical significance of each eigenvector using Tracy-Widom (TW) statistics as described by Patterson et al. and calculated the total variation explained by the significant eigenvector [36].

Finally, we sought to replicate regions that showed association signals across GAW16 data and at least one of the GWAS. If the associated SNPs were not present (either failed or were not genotyped in the study) in the GAW16 data, we looked at the surrounding region in the GAW data (100-kb region centered on the published associated SNP). If any of the SNPs from these regions showed significance at a replication threshold of $p<0.05$, we imputed this region using HAPMAP data (60 unrelated CEU parents) and assessed association.

\section{Results}

We have identified substantial population substructure in GAW16 RA samples. Figure 1A and 1B show estimated structured likelihood probability of data for cases and controls, respectively. The best fitted model for cases favored the assumption of a two-population model (ancestry proportion $=0.955,0.045)$ and three-population model for controls (ancestry proportion $=0.771$, $0.115,0.074)$. However, a combined case-control data favored a three-population model (ancestry proportion = $0.528,0.257,0.215)$. For controls, the likelihood probabilities for two-, three-, and four-population models are similar and that for cases, the likelihood probabilities for a two- and three-population model is similar. We ran principal-components analysis on the combined cases-control data and calculated TW statistics [36] for the top 10 eigenvectors, and 4 significant eigenvectors $(p>0.05)$ explained $23 \%$ of the variation in the whole dataset. This suggests substantial population structure within GAW16 data.

We initially selected 164 non-HLA associated SNPs from 16 recently published GWAS and 13 candidate gene association studies $\left(p<10^{-5}\right)$ to check for replication in the GAW16 dataset. We found associated SNPs for SLE $(n=49), \mathrm{CD}(n=39), \mathrm{T} 1 \mathrm{D}(n=32), \mathrm{RA}(n=37), \mathrm{CLD}$ $(n=4)$, and MS $(n=9)$. Of these 164 SNPs, 92 SNPs were found in the GAW16 data and evaluated by a direct allelic association test. The remaining 72 SNPs were 

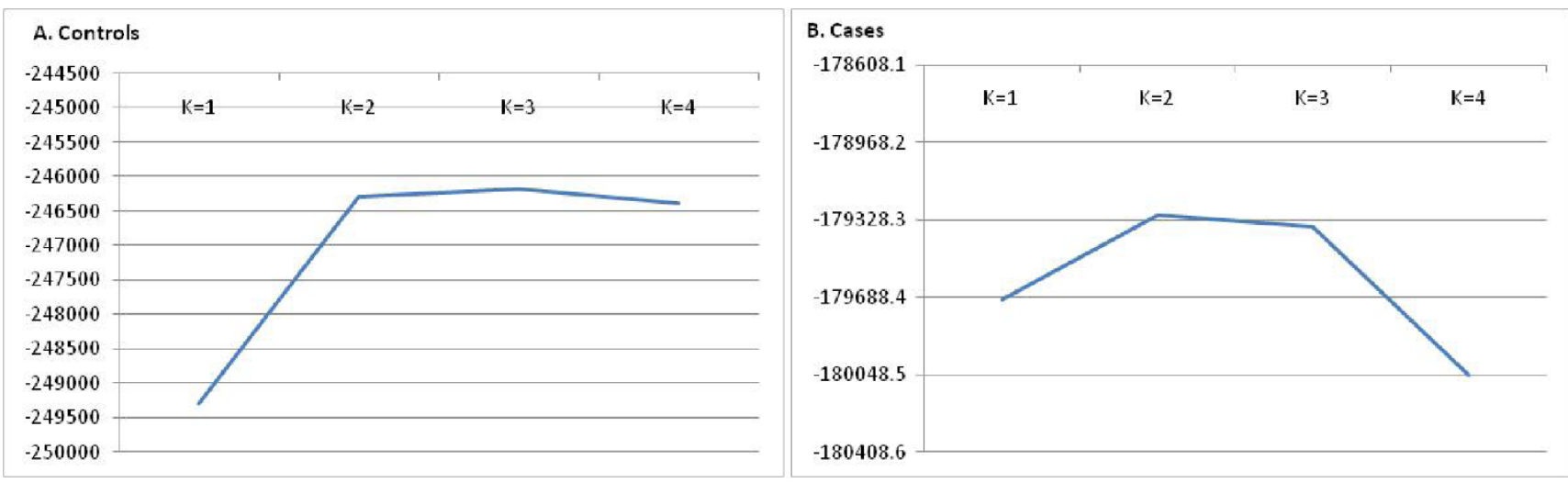

Figure I

Likelihood of data under number of hidden populations (K) estimated separately for controls (A) and cases (B). $\mathrm{K}$ denotes number of populations.

assessed by indirect association (by imputation). Of these 164 SNPs, 29 were significantly replicated $(p<$ $0.05)$. Nine of these SNPs replicated at $p$-values between 0.05 and $0.01,11$ were between 0.01 and $10^{-5}$, and 8 replicated at $p<10^{-5}$. Table 1 shows susceptibility loci with the $p$-values for autoimmune diseases (CD, CLD, T1D, SLE, and RA) identified from various GWAS. The last two columns show association based $p$-values for the same loci in the entire GAW16 RA data and p-values adjusted for population admixture.

\section{Discussion}

There is a growing understanding that susceptibility to autoimmune diseases is due to a complex interaction of multiple genes and environmental factors, and many of these may be shared among many autoimmune diseases. In this analysis we attempted to replicate previously identified associations in multiple autoimmune diseases and inferred regions of shared autoimmunity between GAW16 data and any other autoimmune disease. We did not explore the HLA region in our study because this region has already been extensively investigated and is a very well know complex region of shared autoimmunity among various autoimmune disorders $[37,38]$.

GWAS have emerged as an effective tool to identify common polymorphism underlying complex diseases. One of the major sources of bias in GWAS is population stratification, a variation of ancestry proportions between cases and controls. This stratification can lead to differences in allele frequency between cases and controls unrelated to disease status, consecutively leading to an increased type 1 error [9]. We used 343 AIMs and applied them to cases and controls separately to infer population structure. We have demonstrated substantial population substructure in both cases and controls. In fact, we have identified more sub-structure in controls than cases. Obviously, this would have major impact if not corrected properly while performing association studies.

We identified 16 different cytogenetic regions of shared autoimmunity between GAW16 data and at least one of the proposed autoimmune diseases. There were eight shared regions with SLE (1p13, 2q32.2-q32.3, 6p21.32, 6q23, 8p21.3, 8p23.1, 22q11.21, 22q13.2), six shared regions with $\mathrm{CD}(1 \mathrm{p} 31,3 \mathrm{p} 21,5 \mathrm{p} 13,6 \mathrm{q} 27,10 \mathrm{q} 24,19 \mathrm{q} 13)$, four shared regions with RA (1p13, 2q32.2-q32.3, 4q27, 9q33.2), four shared regions with T1D (1p13, 2q24, 2q33, $4 \mathrm{q} 27)$, and one shared region with CLD (4q27). Interestingly, PTPN22 (1p13), STAT4 (2q32.2-q32.3), and KIAA1109 (4q27) were all associated with multiple autoimmune disease. It should also be noted that SLE shared the most susceptibility genes with RA, suggesting common underlying pathologic processes perpetrated by common loci. These associations are constant, robust, and persisted after correcting for population structure. It is also noteworthy to report that none of the nine associated SNPs from MS are replicated in the GAW16 RA data.

However, our study was not an exhaustive replication with RA and the five other autoimmune diseases because SNPs were chosen using a predefined threshold $\left(p<10^{-5}\right)$. It is possible that SNPs that showed weak to moderate association $\left(0.05-10^{-5}\right)$ with other autoimmune disease could have been highly associated with RA. Also, the other studies from which the list of 164 non-HLA SNPs were selected do not all control for population admixture so it is possible that we missed analyzing an important SNP in the GAW16 data. We did not evaluate that possibility. It is worth future research to look more exhaustively at SNPs 
Table I: Replication of association in multiple autoimmune diseases

\begin{tabular}{|c|c|c|c|c|c|c|c|c|}
\hline \multirow[b]{2}{*}{$\begin{array}{l}\text { Chromosome } \\
\text { number }\end{array}$} & \multirow[b]{2}{*}{$\begin{array}{l}\text { Cytogenetic } \\
\text { position }\end{array}$} & \multirow[b]{2}{*}{ Gene } & \multirow[b]{2}{*}{ SNP } & \multirow[b]{2}{*}{$\begin{array}{l}\text { Physical } \\
\text { position }\end{array}$} & \multirow[b]{2}{*}{$\begin{array}{l}\text { Associated } \\
\text { diseases }\end{array}$} & \multirow[b]{2}{*}{$\begin{array}{l}\text { Uncorrected } \\
\text { GAW p-value }\end{array}$} & \multicolumn{2}{|c|}{ Corrected $p$-value } \\
\hline & & & & & & & $\begin{array}{l}\text { Adjusting } \\
\text { with } \\
\text { ancestry as } \\
\text { covariate in } \\
\text { a logistic } \\
\text { regression } \\
\text { model }\end{array}$ & SAT $^{\mathbf{b}}$ \\
\hline I & $|p 3|$ & IL23R & rsI|465804 & $674 \mid 4547$ & $C D$ & $1.09 \times 10^{-3}$ & $1.04 \times 10^{-3}$ & $2.04 \times 10^{-3}$ \\
\hline I & $|p| 3$ & PTPN22 & rs247660I & 114089610 & $\begin{array}{l}\text { SLE, RA, } \\
\text { TID }\end{array}$ & $1.12 \times 10^{-12}$ & $1.76 \times 10^{-10}$ & $2.66 \times 10^{-10}$ \\
\hline 2 & $2 q 24$ & $\mid F I H I$ & rs|990760 & 162949558 & TID & $6.54 \times 10^{-3}$ & $2.74 \times 10^{-2}$ & $2.44 \times 10^{-2}$ \\
\hline 2 & $2 q 32.2-q 32.3$ & STAT4 & rs6752770 & 191681808 & RA, SLE & $7.00 \times 10^{-3}$ & $1.36 \times 10^{-2}$ & $3.36 \times 10^{-2}$ \\
\hline 3 & $3 p 21$ & MSTI & rs3197999 & 49696536 & CD & $2.31 \times 10^{-2}$ & $3.57 \times 10^{-2}$ & $3.57 \times 10^{-2}$ \\
\hline 4 & $4 q 27$ & KIAAIIO9 & $r s 13151961$ & 123473107 & $\begin{array}{c}\text { Celiac TID, } \\
\text { RA }\end{array}$ & $4.81 \times 10^{-2}$ & $2.74 \times 10^{-2}$ & $3.74 \times 10^{-2}$ \\
\hline 5 & $5 p / 3$ & PTGER4 & rs4613763 & 40428485 & $C D$ & $1.96 \times 10^{-3}$ & $7.56 \times 10^{-3}$ & $5.56 \times 10^{-3}$ \\
\hline 6 & $6 q 23$ & near TNFAIP3 & rs6933404 & 138000928 & SLE & $3.13 \times 10^{-4}$ & $2.01 \times 10^{-3}$ & $3.01 \times 10^{-3}$ \\
\hline 6 & $6 q 23$ & near TNFAIP3 & rs|3|9284| & | 38008907 & SLE & $2.93 \times 10^{-4}$ & $5.71 \times 10^{-4}$ & $6.47 \times 10^{-4}$ \\
\hline 6 & $6 q 23$ & near TNFAIP3 & rs|2527282 & 138008945 & SLE & $2.28 \times 10^{-4}$ & $3.37 \times 10^{-4}$ & $2.27 \times 10^{-4}$ \\
\hline 6 & $6 q 23$ & near TNFAIP3 & rs2327832 & $|380| 476 \mid$ & SLE & $1.06 \times 10^{-4}$ & $7.51 \times 10^{-4}$ & $6.51 \times 10^{-4}$ \\
\hline 6 & $6 q 23$ & near TNFAIP3 & rs6024l4 & 138053358 & SLE & $6.03 \times 10^{-4}$ & $1.29 \times 10^{-2}$ & $1.29 \times 10^{-2}$ \\
\hline 6 & $6 q 27$ & CCR6 & rs 2301436 & 167408399 & $C D$ & $1.67 \times 10^{-2}$ & $1.74 \times 10^{-2}$ & $4.25 \times 10^{-2}$ \\
\hline 8 & $8 p 23.1$ & $X K R 6$ & rsII 783247 & 10826285 & SLE & $4.50 \times 10^{-2}$ & $1.76 \times 10^{-2}$ & $5.77 \times 10^{-2}$ \\
\hline 8 & $8 p 21.1$ & C8orfl 2 & rs7836059 & II 309574 & SLE & $8.87 \times 10^{-3}$ & $1.36 \times 10^{-2}$ & $6.78 \times 10^{-2}$ \\
\hline 8 & $8 p 21.3$ & C8orfI 3-BLK & rs 2736340 & $1|38| 382$ & SLE & $1.45 \times 10^{-5}$ & $2.38 \times 10^{-5}$ & 0 \\
\hline 8 & $8 p 21.3$ & C8orfI 3-BLK & rs|3277|I3 & II 386595 & SLE & $3.46 \times 10^{-6}$ & $5.69 \times 10^{-6}$ & 0 \\
\hline 8 & $8 p 23.1$ & $B L K$ & rs2618476 & II 389950 & SLE & $3.21 \times 10^{-6}$ & $4.10 \times 10^{-6}$ & $*^{\mathrm{c}}$ \\
\hline 8 & $8 p 23.1$ & $B L K$ & rs2248932 & II 429059 & SLE & $9.79 \times 10^{-3}$ & $6.49 \times 10^{-3}$ & $6.69 \times 10^{-3}$ \\
\hline 9 & $9 q 33.2$ & PHFI9 & rs 1953126 & $|2268032|$ & RA & $2.76 \times 10^{-8}$ & $4.97 \times 10^{-8}$ & 0 \\
\hline 9 & $9 q 33.2$ & PHFI9 & rsl609810 & 122682172 & RA & $1.79 \times 10^{-8}$ & $3.38 \times 10^{-8}$ & $*$ \\
\hline 9 & $9 q 33.2$ & PHFI9 & rs88I375 & 122692719 & RA & $2.27 \times 10^{-8}$ & $4.55 \times 10^{-8}$ & 0 \\
\hline 9 & $9 q 33.2$ & PHFI9 & rs6478486 & 122695150 & RA & $1.79 \times 10^{-8}$ & $3.38 \times 10^{-8}$ & $*$ \\
\hline 9 & $9 q 33.2$ & near PHFI 9 & rs376|847 & | 20769793 & RA & $1.24 \times 10^{-8}$ & $3.88 \times 10^{-8}$ & 0 \\
\hline 9 & $9 q 33.2$ & C5 & rs 2900180 & $|2277686|$ & RA & $6.24 \times 10^{-9}$ & $1.88 \times 10^{-8}$ & 0 \\
\hline 10 & $10 q 24$ & $N K X 2-3$ & rsIII90I40 & 101281583 & $C D$ & $4.93 \times 10^{-2}$ & $8.10 \times 10^{-2}$ & $8.80 \times 10^{-2}$ \\
\hline 19 & $19 q 13$ & RSHLI & rs8III07I & 50999246 & $C D$ & $5.91 \times 10^{-5}$ & $1.66 \times 10^{-4}$ & 0 \\
\hline 22 & $22 q l 1.21$ & UBE2L3 & rs5754217 & 20264229 & SLE & $8.94 \times 10^{-3}$ & $6.34 \times 10^{-3}$ & $6.57 \times 10^{-3}$ \\
\hline 22 & $22 q 13.2$ & SCUBEI & rs2071725 & 41934258 & SLE & $2.23 \times 10^{-2}$ & $1.83 \times 10^{-2}$ & $1.57 \times 10^{-2}$ \\
\hline
\end{tabular}

${ }^{\text {a }}$ Allelic association test.

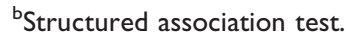

c*, Imputed SNP.

found by GWAS and candidate gene analyses that do not pass genome-wide significance but are significant at the $p<0.05$ level.

\section{Conclusion}

It has long been suspected that autoimmune diseases may share common pathogenesis and susceptibility genes, and several recent studies [4,5] support this hypothesis. Identification of these shared regions can help in identification of novel genetic pathways in autoimmune disease causation, can increase understanding higher prevalence of different autoimmune disorders in families, and may identify targeted regions for gene therapy. Our study successfully identified 16 areas of shared susceptibility involving RA and other autoimmune diseases. These can be further explored by association and clinical studies to solve the conundrum of shared autoimmunity amongst various autoimmune diseases.

\section{List of abbreviations used}

AIM: Ancestry informative marker; CD: Crohn disease; CLD: Celiac disease; GAW: Genetic Analysis Workshop; MS: Multiple sclerosis; PBMC: Peripheral blood mononuclear cells; RA: Rheumatoid arthritis; SAT: Structured association test; SLE: Systemic lupus erythematosus; T1D: Type 1 diabetes; TW: Tracy-Widom.

\section{Competing interests}

The authors declare that they have no competing interests. 


\section{Authors' contributions}

SKN conceived of the study, and participated in its design and coordination and helped to draft the manuscript. HAD and XK-H did the analysis and drafted the manuscript.

\section{Acknowledgements}

The genetic analysis workshops are supported by $\mathrm{NIH}$ grant ROI GM031575 from the National Institute of General Medical Sciences, and ROI Al063622 from the National Institute of Allergy and Infectious Diseases.

This article has been published as part of BMC Proceedings Volume 3 Supplement 7, 2009: Genetic Analysis Workshop 16. The full contents of the supplement are available online at http://www.biomedcentral.com/ $1753-656 \mid / 3$ ? issue $=$ S7.

\section{References}

I. Marrack P, Kappler J and Kotzin BL: Autoimmune disease: why and where it occurs. Nat Med 2001, 7:899-905.

2. Olsen N, Sokka T, Seehorn CL, Kraft B, Maas K, Moore J and Aune TM: A gene expression signature for recent onset rheumatoid arthritis in peripheral blood mononuclear cells. Ann Rheum Dis 2004, 63:1387-1392.

3. Bennett L, Palucka AK, Arce E, Cantrell V, Borvak J, Banchereau J and Pascual V: Interferon and granulopoiesis signatures in systemic lupus erythematosus blood. I Exp Med 2003, | $97: 7 \mid$ I-723.

4. Alarcón-Riquelme ME: A RUNX trio with a taste for autoimmunity. Nat Genet 2003, 35:299-300.

5. Wellcome Trust Case Control Consortium: Genome-wide association study of 14,000 cases of seven common diseases and 3,000 shared controls. Nature 2007, 447:66I-678.

6. Chang M, Rowland CM, Garcia VE, Schrodi SJ, Catanese JJ, Helm-van Mil van der AH, Ardlie KG, Amos Cl, Criswell LA, Kastner DL, Gregersen PK, Kurreeman FA, Toes RE, Huizinga TW, Seldin MF and Begovich $A B$ : A large-scale rheumatoid arthritis genetic study identifies association at chromosome 9q33.2. PLoS Genet 2008, 4:el000107.

7. Remmers EF, Plenge RM, Lee AT, Graham RR, Hom G, Behrens TW, de Bakker PI, Le JM, Lee HS, Batliwalla F, Li W, Masters SL, Booty MG, Carulli JP, Padyukov L, Alfredsson L, Klareskog L, Chen WV, Amos Cl, Criswell LA, Seldin MF, Kastner DL and Gregersen PK: STAT4 and the risk of rheumatoid arthritis and systemic lupus erythematosus. N Engl J Med 2007, 357:977-986.

8. Hom G, Graham RR, Modrek B, Taylor KE, Ortmann W, Garnier S, Lee AT, Chung SA, Ferreira RC, Pant PV, Ballinger DG, Kosoy R, Demirci FY, Kamboh MI, Kao AH, Tian C, Gunnarsson I, Bengtsson AA, Rantapää-Dahlqvist S, Petri M, Manzi S, Seldin MF, Rönnblom L, Syvänen AC, Criswell LA, Gregersen PK and Behrens TW: Association of systemic lupus erythematosus with C8orfi3-BLK and ITGAM-ITGAX. N Engl J Med 2008, 358:900-909.

9. Graham RR, Cotsapas C, Davies L, Hackett R, Lessard CJ, Leon JM, Burtt NP, Guiducci C, Parkin M, Gates C, Plenge RM, Behrens TW, Wither JE, Rioux JD, Fortin PR, Graham DC, Wong AK, Vyse T], Daly MJ, Altshuler D, Moser KL and Gaffney PM: Genetic variants near TNFAIP3 on 6q23 are associated with systemic lupus erythematosus. Nat Genet 2008, 40: |059-106|.

10. Musone SL, Taylor KE, Lu TT, Nititham J, Ferreira RC, Ortmann W, Shifrin N, Petri MA, Kamboh MI, Manzi S, Seldin MF, Gregersen PK, Behrens TW, Ma A, Kwok PY and Criswell LA: Multiple polymorphisms in the TNFAIP3 region are independently associated with systemic lupus erythematosus. Nat Genet 2008, 40:1062-1064.

II. International Consortium for Systemic Lupus Erythematosus Genetics (SLEGEN), Harley JB, Alarcón-Riquelme ME, Criswell LA, Jacob CO, Kimberly RP, Moser KL, Tsao BP, Vyse TJ, Langefeld CD, Nath SK, Guthridge JM, Cobb BL, Mirel DB, Marion MC, Williams AH, Divers J, Wang W, Frank SG, Namjou B, Gabriel SB, Lee AT, Gregersen PK, Behrens TW, Taylor KE, Fernando M, Zidovetzki R, Gaffney PM, Edberg JC,
Rioux JD, Ojwang JO, James JA, Merrill JT, Gilkeson GS, Seldin MF, Yin H, Baechler EC, Li QZ, Wakeland EK, Bruner GR, Kaufman KM and Kelly JA: Genome-wide association scan in women with systemic lupus erythematosus identifies susceptibility variants in ITGAM, PXK, KIAAI542 and other loci. Nat Genet 2008, 40:204-210.

12. Barrett JC, Hansoul S, Nicolae DL, Cho JH, Duerr RH, Rioux JD, Brant SR, Silverberg MS, Taylor KD, Barmada MM, Bitton A Dassopoulos T, Datta LW, Green T, Griffiths AM, Kistner EO, Murtha MT, Regueiro MD, Rotter JI, Schumm LP, Steinhart AH, Targan SR, Xavier RJ, NIDDK IBD Genetics Consortium, Libioulle C, Sandor C, Lathrop M, Belaiche J, Dewit O, Gut I, Heath S, Laukens D, Mni M, Rutgeerts P, Van Gossum A, Zelenika D, Franchimont D, Hugot JP, de Vos M, Vermeire S, Louis E, Belgian-French IBD Consortium; Wellcome Trust Case Control Consortium, Cardon LR, Anderson CA, Drummond H, Nimmo E, Ahmad T, Prescott NJ, Onnie CM, Fisher SA, Marchini J, Ghori J, Bumpstead S, Gwilliam R, Tremelling M, Deloukas P, Mansfield J, Jewell D, Satsangi J, Mathew CG, Parkes M, Georges M and Daly MJ: Genome-wide association defines more than 30 distinct susceptibility loci for Crohn's disease. Nat Genet 2008, 40:955-962.

13. van Heel DA, Franke L, Hunt KA, Gwilliam R, Zhernakova A, Inouye M, Wapenaar MC, Barnardo MC, Bethel G, Holmes GK, Feighery C, Jewell D, Kelleher D, Kumar P, Travis S, Walters JR, Sanders DS, Howdle P, Swift J, Playford RJ, McLaren WM, Mearin ML, Mulder CJ, McManus R, McGinnis R, Cardon LR, Deloukas P and Wijmenga C: A genome-wide association study for celiac disease identifies risk variants in the region harboring IL2 and IL2I. Nat Genet 2007, 39:827-829.

14. International Multiple Sclerosis Genetics Consortium, Hafler DA, Compston A, Sawcer S, Lander ES, Daly MJ, De Jager PL, de Bakker PI, Gabriel SB, Mirel DB, Ivinson AJ, Pericak-Vance MA, Gregory SG, Rioux JD, McCauley JL, Haines JL, Barcellos LF, Cree B, Oksenberg JR and Hauser SL: Risk alleles for multiple sclerosis identified by a genomewide study. N Engl J Med 2007, 357:85I-862.

15. Gregory SG, Schmidt S, Seth P, Oksenberg JR, Hart J, Prokop A, Caillier SJ, Ban M, Goris A, Barcellos LF, Lincoln R, McCauley JL, Sawcer SJ, Compston DA, Dubois B, Hauser SL, Garcia-Blanco MA, Pericak-Vance MA, Haines JL and Multiple Sclerosis Genetics Group: Interleukin 7 receptor alpha chain (IL7R) shows allelic and functional association with multiple sclerosis. Nat Genet 2007, 39:1083-1091.

16. Lundmark F, Duvefelt K, lacobaeus E, Kockum I, Wallström E, Khademi M, Oturai A, Ryder LP, Saarela J, Harbo HF, Celius EG, Salter $H$, Olsson $T$ and Hillert $\mathrm{J}$ : Variation in interleukin 7 receptor alpha chain (IL7R) influences risk of multiple sclerosis. Nat Genet 2007, 39: I 108-I I I3.

17. Todd JA, Walker NM, Cooper JD, Smyth DJ, Downes K, Plagnol V, Bailey R, Nejentsev S, Field SF, Payne F, Lowe CE, Szeszko JS, Hafler JP, Zeitels L, Yang JH, Vella A, Nutland S, Stevens HE, Schuilenburg $H$, Coleman $G$, Maisuria M, Meadows W, Smink LJ, Healy B, Burren OS, Lam AA, Ovington NR, Allen J. Adlem E, Leung HT, Wallace C, Howson JM, Guja C, lonescu-Tîrgoviște C, Genetics of Type I Diabetes in Finland, Simmonds MJ, Heward JM, Gough SC, Wellcome Trust Case Control Consortium, Dunger DB, Wicker LS and Clayton DG: Robust associations of four new chromosome regions from genome-wide analyses of type I diabetes. Nat Genet 2007, 39:857-864.

18. Helgason A, Pálsson S, Thorleifsson G, Grant SF, Emilsson V Gunnarsdottir S, Adeyemo A, Chen Y, Chen G, Reynisdottir I, Benediktsson R, Hinney A, Hansen T, Andersen G, Borch-Johnsen K, Jorgensen T, Schäfer $H$, Faruque M, Doumatey A, Zhou J, Wilensky RL, Reilly MP, Rader DJ, Bagger Y, Christiansen C, Sigurdsson G, Hebebrand J, Pedersen O, Thorsteinsdottir U, Gulcher JR, Kong A, Rotimi $C$ and Stefánsson K: Refining the impact of TCF7L2 gene variants on type 2 diabetes and adaptive evolution. Nat Genet 2007, 39:2 18-225.

19. Zhernakova A, Alizadeh BZ, Bevova M, van Leeuwen MA, Coenen MJ, Franke B, Franke L, Posthumus MD, van Heel DA, Steege van der G, Radstake TR, Barrera P, Roep BO, Koeleman BP and Wijmenga C: Novel association in chromosome 4q27 region with rheumatoid arthritis and confirmation of type I diabetes point to a general risk locus for autoimmune diseases. Am J Hum Genet 2007, 81:1284-1288.

20. Cooper JD, Smyth DJ, Smiles AM, Plagnol V, Walker NM, Allen JE, Downes K, Barrett JC, Healy BC, Mychaleckyj JC, Warram JH and Todd JA: Meta-analysis of genome-wide association study 
data identifies additional type I diabetes risk loci. Nat Genet 2008, 40:|399-|40|.

21. Grant SF, Qu HQ, Bradfield JP, Marchand L, Kim CE, Glessner JT, Grabs R, Taback SP, Frackelton EC, Eckert AW, Annaiah K, Lawson ML, Otieno FG, Santa E, Shaner IL, Smith RM, Skraban R, Imielinski M, Chiavacci RM, Grundmeier RW, Stanley CA, Kirsch SE, Waggott D, Paterson AD, Monos DS, DCCT/EDIC Research Group, Polychronakos $\mathrm{C}$ and Hakonarson $\mathrm{H}$ : Follow-up analysis of genome-wide association data identifies novel loci for type I diabetes. Diabetes 2009, 58:290-295.

22. Franke A, Balschun T, Karlsen TH, Sventoraityte J, Nikolaus S, Mayr G, Domingues FS, Albrecht M, Nothnagel M, Ellinghaus D, Sina C, Onnie CM, Weersma RK, Stokkers PC, Wijmenga C, Gazouli M, Strachan D, McArdle WL, Vermeire S, Rutgeerts $P$, Rosenstiel P, Krawczak M, Vatn MH, IBSEN Study Group, Mathew CG and Schreiber S: Sequence variants in ILIO, ARPC2 and multiple other loci contribute to ulcerative colitis susceptibility. Nat Genet 2008, 40:1319-1323.

23. Raychaudhuri S, Remmers EF, Lee AT, Hackett R, Guiducci C Burtt NP, Gianniny L, Korman BD, Padyukov L, Kurreeman FA, Chang M, Catanese JJ, Ding B, Wong S, Helm-van Mil van der AH, Neale BM, Coblyn J, Cui J, Tak PP, Wolbink GJ, Crusius JB, HorstBruinsma van der IE, Criswell LA, Amos Cl, Seldin MF, Kastner DL, Ardlie KG, Alfredsson L, Costenbader KH, Altshuler D, Huizinga TW, Shadick NA, Weinblatt ME, de Vries N, Worthington J, Seielstad M, Toes RE, Karlson EW, Begovich AB, Klareskog L, Gregersen PK, Daly MJ and Plenge RM: Common variants at CD40 and other loci confer risk of rheumatoid arthritis. Nat Genet 2008, 40:1216-1223.

24. Julià $A$, Ballina J, Cañete JD, Balsa $A$, Tornero-Molina J, Naranjo $A$, Alperi-López M, Erra A, Pascual-Salcedo D, Barceló P, Camps J and Marsal S: Genome-wide association study of rheumatoid arthritis in the Spanish population: KLFI 2 as a risk locus for rheumatoid arthritis susceptibility. Arthritis Rheum 2008, 58:2275-2286.

25. Kozyrev SV, Abelson AK, Woicik J, Zaghlool A, Linga Reddy MP, Sanchez E, Gunnarsson I, Svenungsson E, Sturfelt G, Jönsen A Truedsson L, Pons-Estel BA, Witte T, D'Alfonso S, Barrizzone N, Danieli MG, Gutierrez C, Suarez A, Junker P, Laustrup H, Francisca González-Escribano M. Martin J. Abderrahim H and AlarcónRiquelme ME: Corrigendum: Functional variants in the Bcell gene BANKI are associated with systemic lupus erythematosus. Nat Genet 2008, 40:484.

26. Plenge RM, Seielstad M, Padyukov L, Lee AT, Remmers EF, Ding B, Liew A, Khalili H, Chandrasekaran A, Davies LR, Li W, Tan AK, Bonnard C, Ong RT, Thalamuthu A, Pettersson S, Liu C, Tian C, Chen WV, Carulli JP. Beckman EM, Altshuler D, Alfredsson L, Criswell LA, Amos Cl, Seldin MF, Kastner DL, Klareskog $L$ and Gregersen PK: TRAF I-C5 as a risk locus for rheumatoid arthritis-a genomewide study. N Engl J Med 2007. 357:1199-1209.

27. Kuballa P, Huett A, Rioux JD, Daly MJ and Xavier RJ: Impaired autophagy of an intracellular pathogen induced by a Crohn's disease associated ATG I6LI variant. PLOS ONE 2008, 3:e339I.

28. Libioulle C, Louis E, Hansoul S, Sandor C, Farnir F, Franchimont D, Vermeire S, Dewit O, de Vos M, Dixon A, Demarche B, Gut I, Heath S, Foglio M, Liang L, Laukens D, Mni M, Zelenika D, Van Gossum A, Rutgeerts P, Belaiche J, Lathrop M and Georges M: Novel Crohn disease locus identified by genome-wide association maps to a gene desert on $5 \mathrm{p} / 3.1$ and modulates expression of PTGER4. PLoS Genet 2007, 3:e58.

29. Duggal P, Gillanders EM, Holmes TN and Bailey-Wilson JE: Establishing an adjusted p-value threshold to control the family-wide type I error in genome wide association studies. BMC Genomics 2008, 31:516.

30. Purcell S, Neale B, Todd-Brown K, Thomas L, Ferreira MA Bender D, Maller J, Sklar P, de Bakker PI, Daly MJ and Sham PC: PLINK: a toolset for whole-genome association and population-based linkage analysis. Am J Hum Genet 2007, 81:559-575.

31. FastPHASE. http://depts.washington.edu/ventures/UW Technology/ Express_LicensesfastPHASE.php.

32. Pritchard JK, Stephens M and Donnelly P: Inference of population structure using multilocus genotype data. Genetics 2000, 155:945-959.

33. Tian C, Plenge RM, Ransom M, Lee A, Villoslada P, Selmi C, Klareskog L, Pulver AE, Qi L, Gregersen PK and Seldin MF: Analysis and application of European genetic substructure using $\mathbf{3 0 0}$ K SNP information. PLoS Genet 2008, 4:e4.

34. Price AL, Butler J, Patterson N, Capelli C Pascali VL, Scarnicci $F$ Ruiz-Linares A, Groop L, Saetta AA, Korkolopoulou P, Seligsohn U Waliszewska A, Schirmer C, Ardlie K, Ramos A, Nemesh J,
Arbeitman L, Goldstein DB, Reich D and Hirschhorn JN: Discerning the ancestry of European Americans in genetic association studies. PLoS Genet 2008, 4:e236.

35. Pritchard JK, Stephens M, Rosenberg NA and Donnelly P: Association mapping in structured populations. Am J Hum Genet 2000, 67: $170-|8|$.

36. Patterson N, Price $A L$ and Reich $D$ : Population structure and eigenanalysis. PLoS Genet 2006, 2:el 90.

37. Brand O, Gough S and Heward J: HLA, CTLA-4 and PTPN22 the shared genetic master-key to autoimmunity?. Expert Rev Mol Med 2005, 7:1-15

38. Zanelli E, Breedveld FC and de Vries RR: HLA association with autoimmune disease: a failure to protect?. Rheumatology (Oxford) 2000, 39:1060-1066.
Publish with BioMed Central and every scientist can read your work free of charge

"BioMed Central will be the most significant development for disseminating the results of biomedical research in our lifetime. "

Sir Paul Nurse, Cancer Research UK

Your research papers will be:

- available free of charge to the entire biomedical community

- peer reviewed and published immediately upon acceptance

- cited in PubMed and archived on PubMed Central

- yours - you keep the copyright
BioMedcentral 